\title{
Yield Gap in Agriculture- Evidence from a Northern District of West Bengal, India
}

\author{
K. K. Das*
}

Dept. of Agricultural Economics, Uttar Banga Krishi Viswavidyalaya, Pundibari, Coochbehar, West Bengal (736 165), India

\section{Article History}

Manuscript No. AR1521

Received in $14^{\text {th }}$ June, 2016

Received in revised form $30^{\text {th }}$ July, 2016

Accepted in final form $5^{\text {th }}$ August, 2016

\section{Correspondence to}

*E-mail:kkdas_ubkv@yahoo.com

\section{Keywords}

Crop yield, trend analysis, yield gap, factors

\begin{abstract}
Crop yield is one of the important parameters in judging the farm efficiency. The 'gap' in between the potential frontier of crop yield and the 'achievement' thereof indicates about inefficiency in farming which is thought to be a prime reason for agricultural backwardness in northern part of West Bengal, an important agrarian state in India. The study was undertaken in Coochbehar, a purposively selected West Bengal district, with the objective of exploring the 'magnitude' of yield gap in major crops. The study is based on both primary and secondary data. Time series analysis identifies positive but relatively 'sluggish' pace of growth for yield of major crops in the district. Yield gap was identified separately for smaller (Net cropped area $<1.0 \mathrm{ha}$ ) and larger (Net cropped area $>1.0$ ha) farmers for prevailing major crops like winter paddy, potato, maize, jute and summer paddy etc. Yawning gaps of $1.9 \mathrm{t} \mathrm{ha}^{-1}$ in winter paddy, 3.24 $\mathrm{t} \mathrm{ha}^{-1}$ in summer paddy, $0.54 \mathrm{tha}^{-1}$ in jute etc. do exist in between the experimental yield and the farmers' average yield. The resultant economic loss is also of greater magnitude. Yield gap is relatively more prominent for smaller farmers. Standard of farm family education, degree of extension contact, manures and fertilizer (especially $\mathrm{N}$ ) application has tremendous positive impact on yield improvement and subsequent reduction in 'yield gap'. Regular awareness campaign and training on crop practices alongwith with institutional support are thought to be urgently necessary for improving the 'lagged' situation.
\end{abstract}

\section{Introduction}

Progress and development of social and economic status of farming folk has a functional relationship with the achieved yield in the year round cropping practices (Cassman, K.G, 2010). A farmer, irrespective of his size of holding and resource base, undertakes cultivation of crops during different seasons in a year. But the cropping performance continues to remain below par the potential and coupled with fluctuating \& low output price situation, the farm family often suffers a sustained loss in farm earning. And being dependent on sole occupation (i.e., farming, as because alternative ventures are non accessible due to various reasons), low farm income does affect the investment capacity in the subsequent crop and reaping of good farm income. The overall farm family's economic situation suffers. He becomes compelled to live in a subsistence standard.

The situation is common all over the country and northern part of Bengal is not an exception to that. Rather, farming performance is not at all encouraging in this part of the state (Institute of Applied Manpower Research, New Delhi,
2002). A comparative look reveals that northern districts of West Bengal lags in yield parameter in most of the crops when compared to those of state or national figure, not to speak of the global scenario. As for example, grain yield of winter (aman) paddy hovers around $2.27 \mathrm{t} \mathrm{ha}^{-1}$ compared to the state average of $2.61 \mathrm{t} \mathrm{ha}^{-1}$ and national average of $2.33 \mathrm{t} \mathrm{ha}^{-1}$ (Table 1). This is the case for all the major crops in the region. What is discerning in this respect is that the yield seems to be stagnated in a level and showing hardly any upswing in the previous years. Question comes, why this lagging and stagnation in the overall crop performance? Is the system lagging due to resource crunch situation or laggard mental ability or something else? Can we not improve the situation by simply intermingling certain things (cultural as well as technical) which are not beyond the reach of average farmers? Realistic solutions are required to close yield gaps in both small and large scale cropping systems. It is, therefore, urgently needed to identify the exact magnitude of yield gap, possible underlying factors thereto and that, too, with differing farming situations (i.e., for small land holding and large land holding). To make progress in this direction, we need (1) 
definitions and techniques to measure and model yield at different levels (actual, attainable, potential) (2) identification of the causes of gaps between yield levels; (3) management options to reduce the gaps wherever feasible and (4) policies to favour adoption of gap-closing technologies (Sadras et al, 2015). Hence, a study was conducted in one of the North Bengal districts (i.e, Coochbehar) where dependency solely on farming is mostly pre-dominant. Almost negligible development in industrial sector leads to no option but greater dependency on agriculture in this district. The district with $3,387 \mathrm{~km}^{-2}$ geographical area $(3.82 \%$ of state land mass) shares about one-fifth of region's (North Bengal) population which is highly dense (density : $732 \mathrm{~km}^{-2}$; www.coochbehar. nic.in).

\section{Materials and Methods}

The study is based on experimental findings, primary \& secondary data. For elucidating gap in yield, trials on seasonal major crops have been conducted both at village level (called Demonstration Trial) as well as at research station level (called, Experimental/Research Trial). A total of six (one in each selected village in the district) Demonstration trials and one Experimental trials (in experimental farm at University main campus, Pundibari, Coochbehar) have been conducted. Standard/recommended agronomic package of practices have been strictly followed in conducting the trials which continued for consecutive three agricultural years i.e., 2010-11, 2011-12, 2012-13. Year-wise yield and related data for seasonal crops have been recorded.

For, primary data, multi-stage random sampling method was employed. The district of Coochbehar is selected purposively. The district is having 12 blocks and two blocks namely, Coochbehar-I \& Coochbehar-II have been selected randomly from among these. Three adjoining villages (forming a cluster) from each block have been selected randomly. Data regarding cropping pattern and cropping sequence, input use, social and economic attributes etc. have been collected from a sample strength of 50 farmers from one of these three villages. Thus, a total of 100 farming folk form the ultimate sampling unit. Primary data pertaining to the agricultural year 2011-12 have been collected by following door-door survey method with a pre-tested questionnaire on the purpose. Sampled farming folk have been divided into two categories: (I) Category-I, having net cultivable area upto 1.0 ha $(n=72)$, (II) CategoryII, having net cultivable area above 1.0 ha $(n=28)$. The obtained data (experimental, demonstration, primary) have been duly tabulated and subjected to suitable econometric analysis following standard data analytical tool (i.e., SPSS).

\section{Results and Discussion}

\subsection{Growth performance in yield of major crops}

Before delving into the observation from primary data, an idea about growth performance of yield parameter of major agricultural crops in Coochbehar is obtained by critically perusing Table 1 and 2. A comparative look towards yield performance of major crops in Coochbehar does suggest that the district lags (Table 1) in respect of most of the crops (paddy, wheat, oilseeds, pulses, jute) and that too in comparison to

\begin{tabular}{|c|c|c|c|c|c|}
\hline Major crops & $\begin{array}{l}\text { Unit of } \\
\text { expre- } \\
\text { ssion }\end{array}$ & $\begin{array}{l}\text { Cooch- } \\
\text { behar }\end{array}$ & $\mathrm{NB}^{\#}$ & $\mathrm{WB}^{\# \#}$ & India \\
\hline Winter paddy & $\mathrm{tha}^{-1}$ & 2.06 & 2.27 & 2.61 & 2.33 \\
\hline Summer paddy & $\mathrm{t} \mathrm{ha} \mathrm{h}^{-1}$ & 2.87 & 2.97 & 3.37 & 3.27 \\
\hline Total paddy & $\mathrm{t} \mathrm{ha}^{-1}$ & 2.20 & 2.31 & 2.79 & 2.42 \\
\hline Wheat & $\mathrm{t} \mathrm{ha}^{-1}$ & 2.21 & 2.85 & 2.79 & 3.15 \\
\hline Maize & $\mathrm{t} \mathrm{ha}^{-1}$ & 5.76 & 3.99 & 4.06 & 2.58 \\
\hline Oilseeds & $\mathrm{t} \mathrm{ha}^{-1}$ & 0.50 & 0.80 & 1.18 & 1.17 \\
\hline Pulses & $\mathrm{t} \mathrm{ha}^{-1}$ & 0.71 & 0.82 & 0.84 & 0.79 \\
\hline Potato & $\mathrm{t} \mathrm{ha}^{-1}$ & 25.51 & 24.85 & 21.90 & 21.10 \\
\hline Jute & $\mathrm{t} \mathrm{ha}^{-1}$ & 2.33 & 2.36 & 2.70 & 2.45 \\
\hline
\end{tabular}

*Data pertains to Coochbehar and North Bengal corresponds to 2011-12; "NB: North Bengal; "\#WB: West Bengal

the corresponding national, state \& regional figure. However, promising performance is noticed in case of maize and potatotwo most up-swinging crops in the recent years in the district. This being the current scenario, an attempt have been made to understand the growth performance (Boyce, 1987) of these crops in the district since 1980. Time series analysis has been undertaken with general fitting of exponential functional form $\left(\mathrm{y}=\mathrm{a} \mathrm{e}^{\mathrm{bt}}\right)$ for its greater acceptability (Chattopadhyay and Das, 2000) and advantage of rather direct calculation of growth rate (Compound Annual Growth Rate-CAGR). Relatively better adjusted $\mathrm{R}^{2}$ values of fitted trend equation in most of the cases also justify the choice of the functional form. Trend analysis has been undertaken by dividing the total period (32 years) in two equal halves: period I (198081 to $1995-96)$ \& period-II (1995-96 to 2011-12). It can be observed from Table 2 that all the crops registered positive growth rate in yield during the $1980-81$ to $2011-12$ period : spectacular growth is noticed in maize (CAGR: $9 \%$ annum $^{-1}$, SAGR: $7.18 \%$ annum $^{-1}$ ), potato (CAGR: 4.5\% annum $^{-1}$, SAGR: $9.98 \%$ annum $^{-1}$ ). Also, growth rate in yield of paddy (CAGR: $2.60 \%$ annum $^{-1}$ ), jute (CAGR: $2.00 \%$ annum $^{-1}$ ) and mustard (CAGR: $1.20 \%$ annum $^{-1}$ ) is moderate. But what is discerning is that some of these crops like potato and mustard registered negative growth rate in yield attribute in the later phase (phase-II: 1995-96 to 2011-12).

\subsection{Socio-technical attributes of farming folk}

As stated above, the yield performance of agricultural crops 


\begin{tabular}{|c|c|c|c|c|c|c|}
\hline \multirow[t]{2}{*}{ Crop } & \multicolumn{3}{|c|}{ Simple annual growth rate (SAGR) } & \multicolumn{3}{|c|}{ Compound annual growth rate (CAGR) } \\
\hline & Period-I (\%) & Period-II $(\%)$ & Overall $(\%)$ & Period-I (\%) & Period-II (\%) & Overall (\%) \\
\hline Winter paddy & 0.65 & 3.98 & 2.61 & $1.10^{*}$ & $3.40^{* *}$ & $1.90^{* *}$ \\
\hline Summer paddy & -2.02 & 1.13 & -0.13 & $-1.40^{*}$ & $0.20^{\mathrm{NS}}$ & $0.01^{\mathrm{NS}}$ \\
\hline Total paddy & 1.56 & 3.82 & 3.62 & $2.50^{* *}$ & $3.10^{* *}$ & $2.60^{* *}$ \\
\hline Wheat & 0.15 & 2.61 & 1.20 & $-0.70^{\mathrm{NS}}$ & $1.50^{*}$ & $0.50^{\mathrm{NS}}$ \\
\hline Maize & - & - & 7.18 & - & - & $9.00^{*}$ \\
\hline Rape and mustard & 4.14 & -0.93 & 1.81 & $5.80^{* *}$ & $-1.70^{\mathrm{NS}}$ & $1.20^{*}$ \\
\hline Total pulses & -0.92 & 2.07 & 0.70 & $-1.00^{\mathrm{NS}}$ & $1.70^{*}$ & $0.30^{\mathrm{NS}}$ \\
\hline Potato & 14.29 & 1.56 & 9.98 & $6.80^{* *}$ & $-1.10^{\mathrm{NS}}$ & $4.50^{* *}$ \\
\hline Jute & 0.33 & 4.41 & 2.51 & $1.00^{*}$ & $2.50^{* *}$ & $2.00^{* *}$ \\
\hline
\end{tabular}

${ }^{*} p<0.05 ;{ }^{* *} p<0.001 ; \mathrm{NS}$ : Non significant

from secondary information in the district has been validated with findings from primary information too. As the production efficiency of general farmers largely depend upon his/her socio-economic attributes, we try to understand the ground scenario in this regard. In general, farmers with relatively smaller land holding have little backwardness comparing to their larger counterparts-be it in standard of education ${ }^{1}$ or extension contact ${ }^{2}$. But, in respect of farming practices, the farmers of category-I are doing it more intensely (Table 3 ). What is the matter of great concern is that a certain part of the net cultivable area remains fallow in all the three agricultural seasons irrespective of category. In a rice-based cropping system, winter (aman) paddy is supposed to cover cent per cent of NCA in kharif season and the picture that a certain part (about 14\%) of it remaining non-utilized during that season is surely a matter of concern (similar observation made by Anjani Kumar et al., 2012).

At the same time, this gives the opportunity of incorporating some suitable crops (may be season-specific vegetables etc.) in the cropping sequence at that period. This is expected to have probable influence on yield performance in totality. In the pre-kharif (kharif-1) season, jute crop is undertaken which makes up about $30 \%$ of NCA, in general. But greater percentage of area allocation under jute is more in smaller farmers. Due to erratic nature of farm harvest price of jute, the acreage allocation is instable and larger farmers seem to be more conscious about it. There is every scope for taking up summer vegetables and short duration pulse crops in the void areas during this season. The district is a traditional belt for rabi (winter) crops like wheat, mustard, potato, tobacco etc.

Table 3: Some socio-technical attributes of farming folk in Coochbehar district

\begin{tabular}{llcccc}
\hline Sl. No. & Attribute & $\begin{array}{c}\text { Unit of } \\
\text { expression }\end{array}$ & $\begin{array}{c}\text { Category-I } \\
(<1.0 \text { ha })\end{array}$ & $\begin{array}{c}\text { Category-II } \\
(>1.0 \text { ha })\end{array}$ & Overall \\
\hline 1. & Farm family size & nos. & 4.67 & 5.67 & 4.95 \\
2. & Male: Female ratio & ratio & $1.33: 1.0$ & $1.28: 1.0$ & $1.31: 1.0$ \\
3. & Farm family education & score & 1.39 & 1.63 & 1.46 \\
4. & Age of decision-making head & yrs. & 50.75 & 59.08 & 53.08 \\
5. & Education of decision making head & score & 1.39 & 1.32 & 1.37 \\
6. & Index for cosmopolitanism & score & 1.96 & 2.84 & 2.21 \\
7. & Major source of information & - & Fertilizer shop & Fertilizer shop & Fertilizer shop \\
8. & Net cropped area (NCA) & ha & 0.37 & 1.26 & 0.62 \\
9. & Average size of plot & ha & 0.20 & 0.38 & 0.25 \\
10. & Cropping Intensity & $\%$ & 209.00 & 189.37 & 204.57 \\
11. & Void area during kharif & $\%$ & 11.87 & 15.04 & 12.58 \\
12. & Void area during rabi & $\%$ & 37.53 & 47.15 & 39.70 \\
13. & Void area during pre-kharif & $\%$ & 41.60 & 48.44 & 43.14 \\
\hline
\end{tabular}




\begin{tabular}{|c|c|c|c|c|}
\hline Crop & $\begin{array}{l}\text { Unit of } \\
\text { expre- } \\
\text { ssion }\end{array}$ & $\begin{array}{l}\text { Category-I } \\
(\leq 1.0 \text { ha) }\end{array}$ & $\begin{array}{c}\text { Category-II } \\
(>1.0 \text { ha })\end{array}$ & Overall \\
\hline Jute & $\mathrm{t} \mathrm{ha}^{-1}$ & $\begin{array}{c}2.00 \\
(35.88)\end{array}$ & $\begin{array}{c}2.19 \\
(21.55)\end{array}$ & $\begin{array}{c}2.05 \\
(31.87)\end{array}$ \\
\hline Aman & $\mathrm{t} \mathrm{ha}^{-1}$ & $\begin{array}{c}2.92 \\
(86.31)\end{array}$ & $\begin{array}{c}2.84 \\
(84.26)\end{array}$ & $\begin{array}{c}2.89 \\
(85.74)\end{array}$ \\
\hline Potato & $\mathrm{t} \mathrm{ha}^{-1}$ & $\begin{array}{c}24.17 \\
(17.41)\end{array}$ & $\begin{array}{c}25.56 \\
(19.80)\end{array}$ & $\begin{array}{c}24.56 \\
(18.08)\end{array}$ \\
\hline Maize & $\mathrm{t} \mathrm{ha}^{-1}$ & $\begin{array}{c}4.71 \\
(0.41)\end{array}$ & $\begin{array}{c}5.38 \\
(5.75)\end{array}$ & $\begin{array}{c}4.90 \\
(1.91)\end{array}$ \\
\hline Boro & $\mathrm{t} \mathrm{ha}^{-1}$ & $\begin{array}{c}4.82 \\
(2.50)\end{array}$ & $\begin{array}{c}5.41 \\
(0.83)\end{array}$ & $\begin{array}{c}4.99 \\
(2.03)\end{array}$ \\
\hline
\end{tabular}

${ }^{*}$ Figures in parentheses indicate $\%$ share of individual crop in NCA

But, recently, switching towards rabi maize and potato is a growing tendency in this region and this is more pronounced in the relatively larger farmers. Important rabi crops like wheat, mustard, summer paddy are being replaced to accommodate potato, rabi maize and some winter vegetables. Naturally, area under wheat and summer (boro) paddy is on the decline in this area under study.

Now, if we look towards the yield performance according to the farming categories it can be observed that the farming community, in general, lags behind the district average, not to speak of the state or national average in this regard! Of course, this is more true for the smaller farmers than their larger counterparts. As for example, jute yield for smaller farmer is $2.0 \mathrm{t} \mathrm{ha}^{-1}$ which is substantially lower than that of their larger counterparts $\left(2.19 \mathrm{t} \mathrm{ha}^{-1}\right)$ or district average (2.33 $\mathrm{t} \mathrm{ha}^{-1}$ ). In case of kharif paddy (aman), though, the picture is bit encouraging as overall yield level $\left(2.90 \mathrm{tha}^{-1}\right)$ is far better than district, state or national level. More interestingly, small farmers are doing better in this regard.

\subsection{Yield gap : concept and extent}

The concept of yield gap is defined differently by different authors. As for example, Laila Arjuman Ara et al., (2004) refers yield gap as 'the difference between the highest production within the sample farmers and the yield achieved by the sample farmer under study'. Here, the approach is bit different. The gap in yield performance is compared from two points of view : between farmers' field $\left(\mathrm{Y}_{\mathrm{F}}\right)$ and demonstration $\left(\mathrm{Y}_{\mathrm{D}}\right)$ plot, $\left(\mathrm{Y}_{\mathrm{D}}-\mathrm{Y}_{\mathrm{F}}\right)$ and between farmers field $\left(\mathrm{Y}_{\mathrm{F}}\right)$ and experimental plot $\left(\mathrm{Y}_{\mathrm{E}}\right),\left(\mathrm{Y}_{\mathrm{E}}-\mathrm{Y}_{\mathrm{F}}\right)$ (Warade, $\mathrm{S}$ et al, 2008; Barman, S.C, 2005, Bhatia, V.S et al., 2006,). Again, the gap is identified both in terms of physical yield \{hence, abbreviated as $\left(\mathrm{Y}_{\mathrm{EP}}-\mathrm{Y}_{\mathrm{FP}}\right),\left(\mathrm{Y}_{\mathrm{DP}}-\mathrm{Y}_{\mathrm{FP}}\right)$ ) and economic yield \{hence abbreviated as $\left(\mathrm{Y}_{\mathrm{EE}}-\mathrm{Y}_{\mathrm{FE}}\right),\left(\mathrm{Y}_{\mathrm{DE}}-\mathrm{Y}_{\mathrm{FE}}\right)$ \}. While the yield achieved in the Demonstration plots gives an indication about attainable yield with normal care, yield in experimental plots defines a frontier in output considering the local agro-climatic conditions and technological advancement. It is important to know both these types of gap for improvement in the current agrarian situation.

A close perusal of Table 5 reveals existence of yawning gap in physical as well as economic yield in all the major crops in the district and the gap is more for smaller farmers $((\leq 1.0 \mathrm{ha})$ than their larger counterparts. On an average, a per ha yield of 4.80-4.84 $\mathrm{t}\left(\mathrm{Y}_{\mathrm{E}}\right)$ / 3.94-4.01 $\mathrm{t}\left(\mathrm{Y}_{\mathrm{D}}\right)$ of winter (aman) paddy is attainable by following the standard package of practices in the prevailing agro-climatic and given socio-economic situation. The level of gap ranges from $1.05 \mathrm{tha}^{-1}\left(\mathrm{Y}_{\mathrm{DP}}-\mathrm{Y}_{\mathrm{FP}}\right)$ to

Table 5: Magnitude of crop-wise gap in yield

\begin{tabular}{|c|c|c|c|c|c|c|c|}
\hline \multirow[t]{2}{*}{ Crop } & \multirow[t]{2}{*}{$\begin{array}{l}\text { Unit of } \\
\text { expression }\end{array}$} & \multicolumn{3}{|c|}{$\begin{array}{l}\text { Gap in yield between experimental field and } \\
\text { farmers' plot }\left(\mathrm{Y}_{\mathrm{EP}}-\mathrm{Y}_{\mathrm{FP}}\right)\end{array}$} & \multicolumn{3}{|c|}{$\begin{array}{l}\text { Gap in yield between demonstration plot and } \\
\text { farmers' plot }\left(\mathrm{Y}_{\mathrm{DP}}-\mathrm{Y}_{\mathrm{FP}}\right)\end{array}$} \\
\hline & & $\begin{array}{l}\text { Category-I } \\
(\leq 1.0 \text { ha })\end{array}$ & $\begin{array}{l}\text { Category-II } \\
(>1.0 \text { ha })\end{array}$ & Overall & $\begin{array}{l}\text { Category-I } \\
(\leq 1.0 \text { ha })\end{array}$ & $\begin{array}{l}\text { Category-II } \\
(>1.0 \text { ha })\end{array}$ & Overall \\
\hline Jute & $\mathrm{tha}^{-1}$ & $\begin{array}{c}0.58 \\
(34,881.86)\end{array}$ & $\begin{array}{c}0.44 \\
(25,493.19)\end{array}$ & $\begin{array}{c}0.54 \\
(32,253.03)\end{array}$ & $\begin{array}{c}0.16 \\
(11,816.66)\end{array}$ & $\begin{array}{c}0.01 \\
(2,518.98)\end{array}$ & $\begin{array}{c}0.12 \\
(9,213.31)\end{array}$ \\
\hline Aman & $\mathrm{tha}^{-1}$ & $\begin{array}{c}1.92 \\
(30,835.44)\end{array}$ & $\begin{array}{c}1.96 \\
(26,161.98)\end{array}$ & $\begin{array}{c}1.93 \\
(29,526.87)\end{array}$ & $\begin{array}{c}1.02 \\
(17,685.16)\end{array}$ & $\begin{array}{c}1.17 \\
(14,530.48)\end{array}$ & $\begin{array}{c}1.06 \\
(16,801.80)\end{array}$ \\
\hline Potato & $\mathrm{tha}^{-1}$ & $\begin{array}{c}12.84 \\
(161.09)\end{array}$ & $\begin{array}{c}11.83 \\
(1,266.32)\end{array}$ & $\begin{array}{c}12.56 \\
(470.55)\end{array}$ & $\begin{array}{c}9.58 \\
(91.33)\end{array}$ & $\begin{array}{c}8.57 \\
(1,196.56)\end{array}$ & $\begin{array}{c}9.30 \\
(400.79)\end{array}$ \\
\hline Maize & $\mathrm{tha}^{-1}$ & $\begin{array}{c}4.20 \\
(35,269.27)\end{array}$ & $\begin{array}{c}4.10 \\
(29,005.00)\end{array}$ & $\begin{array}{c}4.17 \\
(33,515.27)\end{array}$ & $\begin{array}{c}3.29 \\
(19,977.87)\end{array}$ & $\begin{array}{c}3.04 \\
(24,344.50)\end{array}$ & $\begin{array}{c}3.22 \\
(21,200.53)\end{array}$ \\
\hline Boro & $\mathrm{tha}^{-1}$ & $\begin{array}{c}3.39 \\
(11,080.64)\end{array}$ & $\begin{array}{c}2.84 \\
(914.21)\end{array}$ & $\begin{array}{c}3.24 \\
(8,234.04)\end{array}$ & $\begin{array}{c}1.72 \\
(6,049.87)\end{array}$ & $\begin{array}{c}1.17 \\
(5,944.98)\end{array}$ & $\begin{array}{c}1.57 \\
(6,020.50)\end{array}$ \\
\hline
\end{tabular}

${ }^{*}$ Figures in parentheses indicate magnitude of corresponding gap in economic $\left(₹\right.$ ha $\left.^{-1}\right)$ yield 
$1.93 \mathrm{tha}^{-1}\left(\mathrm{Y}_{\mathrm{EP}}-\mathrm{Y}_{\mathrm{FP}}\right)$. In economic term, this happens to be an average loss of ₹ 17,000/- (aprox.) to ₹ 30,000/- in net return from the venture. Like-wise, while a jute farmer has the frontier of producing $2.58 \mathrm{mt}$ to $2.64 \mathrm{tha}^{-1}$ with the prevailing conditions, he is producing $2.08 \mathrm{t} \mathrm{ha}^{-1}$, thus resulting a 'gap' of about $0.55 \mathrm{t} \mathrm{ha}^{-1}$. Jute is an important crop in the cropping sequence which caters the requirement of cash of a farm family, especially during festivals. Thus, the gap in physical yield results in an economic loss of ₹ 33,000/-. Similar are the cases for other major crops too (Table 5).

As winter (aman) paddy and jute shares the major bulk of NCA, we try to grasp an idea about the frequency of farmers belonging to different ranges (class) of yield gap (Table 6). We got a differential picture for these crops in this regard. While, about $72 \%$ winter (aman) paddy growers have yield gap between $1.5 \mathrm{t} \mathrm{ha}^{-1}$ to $3.0 \mathrm{t} \mathrm{ha}^{-1}$, most (about $80 \%$ ) of the jute growers have relatively less yield gap i.e $0.01 \mathrm{t} \mathrm{ha}^{-1}$ to $1.0 \mathrm{t} \mathrm{ha}^{-1}$. Considering the overwhelming weightage of winter

Table 6 : Intensity of gap in physical yield in jute and winter paddy

\begin{tabular}{|c|c|c|c|c|}
\hline \multirow{2}{*}{$\begin{array}{l}\text { Category of } \\
\text { yield gap }\end{array}$} & \multicolumn{2}{|c|}{ Winter paddy } & \multicolumn{2}{|c|}{ Jute } \\
\hline & $\begin{array}{l}{ }^{*} \text { Y. Gap } \\
\left(\mathrm{t} \mathrm{ha}^{-1}\right)\end{array}$ & $\begin{array}{c}\% \text { of } \\
\text { farmers }\end{array}$ & $\begin{array}{l}{ }^{*} \text { Y. Gap } \\
\left(\mathrm{t} \mathrm{ha}^{-1}\right)\end{array}$ & $\begin{array}{c}\% \text { of } \\
\text { farmers }\end{array}$ \\
\hline$\leq 0.50 \mathrm{t} \mathrm{ha}^{-1}$ & 0.33 & 4.55 & 0.04 & 40.68 \\
\hline$(0.51-1.00) \mathrm{t} \mathrm{ha}^{-1}$ & 0.79 & 5.68 & 0.68 & 40.68 \\
\hline$(1.01-1.50) \mathrm{tha}^{-1}$ & 1.18 & 13.64 & 1.16 & 13.56 \\
\hline$(1.51-2.00) t^{h a-1}$ & 1.78 & 27.27 & 1.85 & 3.39 \\
\hline$(2.01-2.50) \mathrm{t} \mathrm{ha}^{-1}$ & 2.30 & 28.41 & 2.13 & 1.69 \\
\hline$(2.51-3.00) t h^{-1}$ & 2.71 & 17.05 & - & 0.00 \\
\hline$>3.00 \mathrm{t} \mathrm{ha}^{-1}$ & 3.35 & 3.41 & - & 0.00 \\
\hline
\end{tabular}

${ }^{*}$ Y. Gap : Yield gap paddy in the year-round cropping sequence and also sensing the consuming need of this of crop in the food basket, due attention must be given to bridge the identified gap. On the other hand, though jute is a traditionally acclaimed cash crop, relatively lower yield coupled with low and fluctuating output price frustrates the farming folk, in general. Assured price (feasible/rational Minimum Support Price) mechanism and replacement of age-old variety (JRO-524 or Nabin) is primarily required to overcome the situation.

\subsection{Yield gap : factor association}

Now, question comes why this gap in yield? We try to explain the observation by identifying the probable association (liner/ non-linear) of social and technical traits (Ofori et al, 2010) with gap in physical yield winter paddy and jute (Table 7, Figure 1 and 2). It is assumed that overall educational standard of a farm family $\left(\mathrm{x}_{1}\right)$, age (a dummy for judging experience) of decision making head of the farm family $\left(\mathrm{x}_{2}\right)$, extension contact (a dummy for judging dynamicity) of the farm family $\left(\mathrm{x}_{3}\right)$, area allocated under the crop in question $\left(\mathrm{x}_{4}\right)$, application of organic manure $\left(\mathrm{x}_{5}\right)$, application of nitrogen $\left(\mathrm{x}_{6}\right)$, application of phosphorous $\left(\mathrm{x}_{7}\right)$ and application of potassium $\left(\mathrm{x}_{8}\right)$ may be thought of as the prime factors to influence the crop yield performance and the resultant gap in yield (i.e., y). Rather than going with the Multiple Regression technique, it is preferred to identify the association of individual explanatory factors with corresponding yield gap (Lakshmanan, 2007). Curvilinear association is found to be best fit in most of the cases (Table 7).

A close perusal of these figures does reveal that these traits have differential association with yield gap for different crops. But in most of the cases some precise information (regarding association) comes out. As for example, a standard family education around class X (score 2.0) is found to be good for

\begin{tabular}{|c|c|c|c|c|c|c|c|}
\hline \multirow{2}{*}{$\begin{array}{l}\text { Sl. } \\
\text { No. }\end{array}$} & \multirow[t]{2}{*}{ Explaining factor } & \multicolumn{3}{|c|}{ Kharif paddy $(\mathrm{n}=07)$} & \multicolumn{3}{|c|}{ Jute $(n=07)$} \\
\hline & & $\begin{array}{l}\text { Type of best } \\
\text { fit equation }\end{array}$ & Form of equation & $\mathrm{R}^{2}$ & $\begin{array}{l}\text { Type of best } \\
\text { fit equation }\end{array}$ & Form of equation & $\mathrm{R}^{2}$ \\
\hline 1. & Family education & Exponential & $y=25.68 e^{-2.07 x}$ & 0.86 & Polynomial & $y=-0.71+7.04 x-4.15 x^{2}$ & 0.60 \\
\hline 2. & Age of head & Exponential & $y=818.5 e^{-0.12 x}$ & 0.80 & Polynomial & $y=-156.0+5.45 x-0.05 x^{2}$ & 0.91 \\
\hline 3. & Extension contact & Exponential & $\mathrm{y}=24.98 \mathrm{e}^{-1.58 \mathrm{x}}$ & 0.91 & Polynomial & $y=-0.89+4.15 x-1.64 x^{2}$ & 0.96 \\
\hline 4. & Crop acreage & Polynomial & $y=3.48-13.39 x+19.08 x^{2}$ & 0.13 & Polynomial & $y=11.82-40.84 x-36.66 x^{2}$ & 0.83 \\
\hline 5. & Application of manure & Exponential & $\mathrm{y}=5.97 \mathrm{e}^{-0.4 \mathrm{x}}$ & 0.75 & Linear & $y=-0.268+0.266 x$ & 0.38 \\
\hline 6. & $\begin{array}{l}\text { Application of } \mathrm{N} \\
\text { fertilizer }\end{array}$ & Exponential & $y=11.28 e^{-0.04 x}$ & 0.73 & Polynomial & $y=2.11-0.18 x+0.005 x^{2}$ & 0.82 \\
\hline 7. & $\begin{array}{l}\text { Application of } \mathrm{P} \\
\text { fertilizer }\end{array}$ & Polynomial & $y=-2.58+0.54 x-0.014 x^{2}$ & 0.34 & Polynomial & $y=1.97-0.15 x-0.001 x^{2}$ & 0.89 \\
\hline 8. & $\begin{array}{l}\text { Application of K } \\
\text { fertilizer }\end{array}$ & Polynomial & $y=12.77-0.87 x+0.016 x^{2}$ & 0.10 & Polynomial & $y=1.99-0.06 x-0.029 x^{2}$ & 0.98 \\
\hline
\end{tabular}



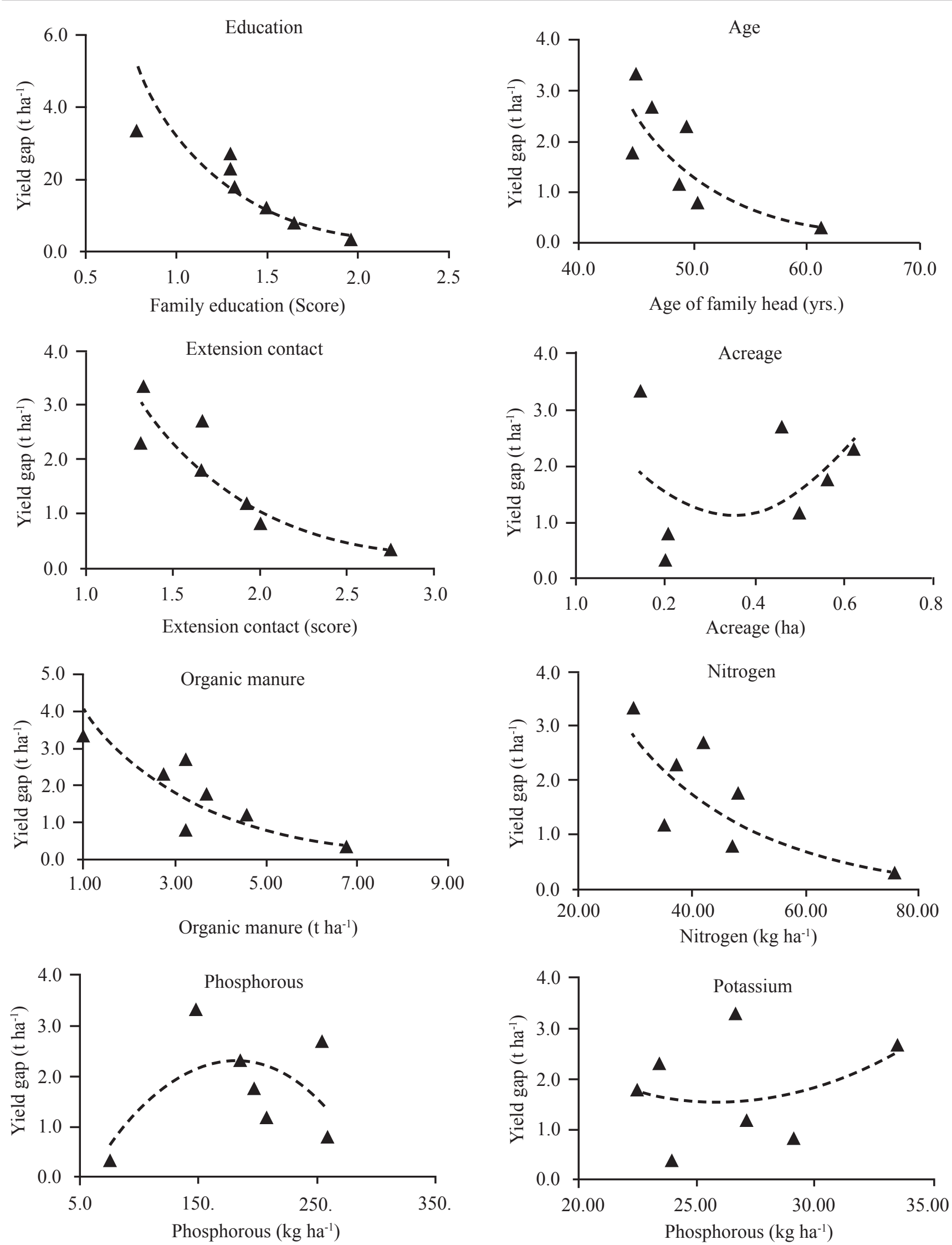

Figure 1 : Association between yield gap and its factors in kharif paddy cultivation 

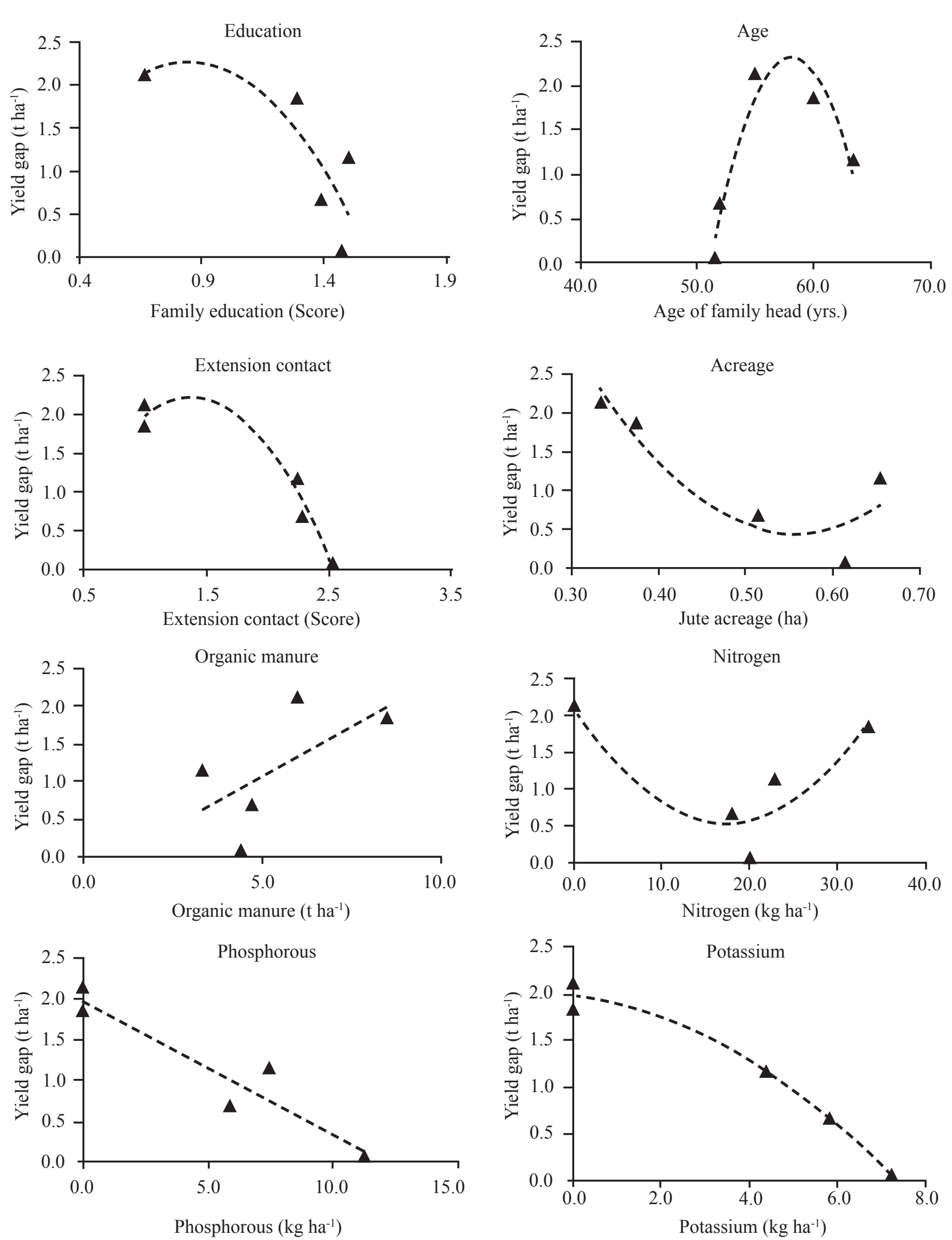

Figure 2: Association between yield gap and its factors in Jute cultivation 
minimisation in gap for both the crop. When a farmer (or his family member (s)) has the attitude of keeping contact with extension agencies (government or non-government institutes/offices), probability of reduction in yield gap results. A decision making head of around 50-60 years is better for achieving minimum gap in yield. Of course, more application of nutrient (organic manure, N, P, K) has the potentiality of increasing yield, in general but for minimisation in gap in yield, there remains a frontier in application threshold for each crop. Surprisingly, required amount of N, P \& K happens to be extremely low for jute which raises doubt. In reality, cultivation of jute crop is taken up after rabi crops like potato, mustard, wheat, tobacco etc. in this region. Relatively greater amounts of nutrients are applied in the field during rabi crops and lesser amount of manures and fertilizers are applied during pre-kharif crops (especially, jute).

\section{Policy Perspective}

Existence of yield gap is one of the probable reasons for relative backwardness of the farming folk of this part of West Bengal. Relatively lower yield fetches lower net income which, in turn, lessens the probability of investing more in the subsequent crop and adopting improved package of practices. This, again, yields lesser output per unit area and so on. The vicious circle continues. Little re-orientation or thoughtful action may lessen this backwardness if not completely removing the gap. By conversing with the farmers and also with the various extension agencies (private and public) following things have to be given due attention to reap a good harvest and even better net return.

- Overall education of the farm family has to be improved for better performance.

- Awareness campaign about cropping practices and its changing is to be undertaken on regular basis.

- Devising suitable mechanism for advocating farming community in choosing the right mix of crops in the sequence. A flat recommendation may not help in this regard.

- Stability in output and input price has to be assured.

- Indiscriminate using of chemicals do harm the fertility of the soil, not to speak of the economic loss. Similar observation was made by Singh, P et al, 2006.

- Rigorous research on 'nutrient management' is urgently required as flat recommendation of fertilizers without due attention towards the inherent soil status is bound to aggravate the problem rather than improving it.

\section{Conclusion}

Failure on the part of farming folk of Coochbehar in achieving the potential yield is really a matter of concern. It is reflexive of the present deplorable scenario of farming practices in entire northern segment of West Bengal. Effective dissemination of technological changes in farm practices, continued capacity building programmes and change in attitude (commercial rather than subsistence) of farming folk are needs of the hour to bridge / reduce the yield gap. Simultaneously, necessary institutional arrangement (regarding access to credit $\&$ water, farm mechanization etc.) has to be carefully thought of.

\section{Acknowledgement}

This paper is the outcome of a Rastriya Krishi Vikash Yozana (RKVY) project namely, "Spatial crop dynamics and yield gap across different farming situations in North Bengal". The author duly acknowledges the help of the farming community of Coochbehar district of West Bengal for their kind cooperation during collection of primary data and also of Dr. J.Ghosh, Assistant Professor, Dept. of Agril. Entomology, U.B.K.V., Dr. P. Poddar, Assistant Professor, Agronomy, R.R.S (Terai), U.B.K.V and other relevant Scientists while conducting Experimental \& Demonstration Trials.

\section{References}

Annonymous, 1978. Statistical Abstract. Bureau of Applied Economics and Statistics, Government of West Bengal, Kolkata.

Annonymous, 1994. Statistical Abstract. Bureau of Applied Economics and Statistics, Government of West Bengal, Kolkata.

Annonymous, 2001. Statistical Abstract. Bureau of Applied Economics and Statistics, Government of West Bengal, Kolkata

Annonymous, 2008. Statistical Abstract. Bureau of Applied Economics and Statistics, Government of West Bengal, Kolkata.

Anonymous, 2002. Report on comparative backwardness of North Bengal, Institute of Applied Manpower Research, New Delhi, 2002: (A study sponsored by Planning Commission, Govt. Of India).

Ara, A.L., Alam, F., Rahman, M., Jabbar, M.A., 2004. Yield Gaps, production losses and technical efficiency of selected groups of fish farmers in Bangladesh. Indian Journal of Agricultural Economics 59(4), 815.

Barman, S.C., Islam, N., 2005. Real Adoption Impact Measure of Potato technologies on production of farmers' level in Comilla district, Bangladesh. Indian Journal of Agricultural Economics 60(4), 677-685.

Bhatia, V.S., Singh, P., Wani, S.P., Kesava Rao, A.V.R., Srinivas, K., 2006. Yield Gap Analysis of Soybean, Groundnut, Pigeonpea and Chickpea in India using Simulation Modeling. Global theme on Agroecosystem Report No. 31, International Crops Research Institute for the Semi-Arid Tropics. Accessed from http://Oar. icrisat.org/2385/1/yield_gap_analysis_of.pdf on $27^{\text {th }}$ 
October, 2015.

Boyce, J.K., 1987. Agrarian impasse in Bengal: Agricultural growth in Bangladesh and West Bengal 1949-1980. Oxford University Press, New York.

Cassman, K.G., 2010. Yield gap analysis: implications for research and policy. Accessed from http://www. agropolis.fr/agro2010/paper/s231A/casman.pdf on 27th October, 2015.

Chattopadhyay, A.K., Das, P.S., 2000. Estimation of rate: a critical analysis with reference to West Bengal agriculture, Indian Journal of Agricultural Economics 55(2), 116-135.

Das, K.K., Das, N, K., 2006. Is sericulture a complementary venture to agriculture - a study from West Bengal? Journal of Interacademicia 10(3), 426-436.

Kumar, A., Kumar, P., Sharma, Sharma, A.N., 2012. Crop diversification in Eastern India: status and determinants. Indian Journal of Agricultural Economics 67(4), 609.

Lakshmanan, S., 2007. Yield gaps in mulberry sericulture in Karnataka: an econometric analysis. Indian Journal of Agricultural Economics 62(4), 626, 628.

Ofori, E., Kyei-Baffour, N., Mensah, E., Agyare, W.A., 2010. Yield gap analysis in rice production from stakeholders' perspective at Annum valley bottom irrigation project at Nobewam in Ghana. ARPN Journal of Agricultural and Biological Science 5(6), 50-57. Accessed from http:// www.arpnjournals.com/jabs/research_papers/rp_2010/ jabs_1110_223.pdf on $27^{\text {th }}$ October, 2015

Sadras, V.O., Cassman, K.G., Grassini, P., Hall, A.J., Bastiaanssen,W.G.M., Laborte, A.G., Milne, A.E., Sileshi, G., Steduto, P., 2015. Yield gap analysis of field crops: methods and case studies. FAO Water Report 41. Food and Agriculture Organization of the United Nations, Rome. Accessed from http://fao.org/3/ai4695e.pdf on $27^{\text {th }}$ October, 2015.

Singh, P., Vijaya, D., Chinh, N.T., Pongkanjana, A., Prasad, K.S., Srinivas, K., Wani, S.P., 2001. Potential productivity and yield gap of selected crops in the rainfed regions of India, Thailand and Vietnam. Natural Resource Management Program Report no. 5. ICRISAT, Hyderabad. Accessed from http://ejournal.icrisat.org on $27^{\text {th }}$ October, 2015.

Warade, S., Kakde, S., Tiwari, V., Alexander, S., 2008. Yield gap analysis in the cotton of Akola district. Journal of Agricultural Development and Policy 18(1\&2), 49.

private sectors. Centro International de Mejoramiento de Maiz y Trigo (CMMYT), Mexico.

CIMMYT, 1995. International maize testing report, 1995. Centro International de Mejoramiento de Maiz y Trigo (CMMYT), Mexico.

CIMMYT, 1996. CIMMYT International maize testing report, 1996. Centro International de Mejoramiento de Maiz y Trigo (CMMYT), Mexico.
DMR, 2001. Annual report, Directorate of Maize Research (DMR), 49 $9^{\text {th }}$ annual maize workshop, Directorate of Maize Research, held at C.S. Azad University of Agriculture and Technology, Kanpur (Uttar Pradesh), India 5-9 April 2001.

Dolan, D.J., Stuthman, D.D., Kolb, F.L., Hewings, A.D., 1996. Multiple traits selection in a recurrent selection population in Oat (Avena sativa L.). Crop Science 36(5), 1207-1211.

Edmeades, G.O., Bolanos, J., Chapman, S.C., Lafitte, H., Banziger, M., 1999. Selection improves drought tolerance in tropical maize population: I. Gains in biomass, grain yield, and harvest index. Crop Science 39(5), 1306-1315.

FAO. 2010. The state of food insecurity in the world. Addressing food insecurity in protracted crisis. Available at http://www.fao.org/publications/sofi /en/ (verified 10 Dec. 2011). Food and Agriculture Organization of the United Nations, Rome, Italy.

Hazel, L.N., 1943. Genetic basis for constructing selection indices. Genetics 28, 476-490.

Katyal, J.C., 1994. Nutrient management in soils of arid and semi-arid regions 79-91. In soil management for sustainable agriculture in Dryland Areas, Bulletin Number 16. Indian Society of Soil Science.

Kauffman, K.D., Dudley, J.W., 1979. Selection indexes for corn grain yield, \% protein and kernel weight. Crop Science, 19, 583-588.

Kebede, S.A., 2007. Genetic studies on low nitrogen tolerance in maize (Zea mays L.). Ph.D. Thesis, G.B. Pant University of Agriculture and Technology, Pantnagar, India 52-53.

Lone, A.A., 2006. Genetic studies on excess soil moisture tolerance in maize (Zea mays L.). Ph.D. Thesis, G.B. Pant University of Agriculture and Technology, Pantnagar, India 107-109.

Modaressi, M., Kheradnam, M., Assad, M.T., 2004. Selection indices as indirect selection in corn hybrids (Zea mays L.) for increasing yield. Iranian Journal of Agriculture Science 35 (1), 115-127.

Mulamba, N.N., Mock, J.J., 1978. Improvement of yield potential of the Eto Blanco maize (Zea mays L.) population by breeding for plant traits. Egyptian Journal of Genetics and Cytology 7, 40-41.

Nawar, A.A., Ibrahim, M.E., Khalil, A.N.M., 1991. The efficiency of three conventional selection indices in corn. Annals of Agriculture Science 29(1), 63-75.

SAA, 2002. Feeding the future-African's crops hunger for improved nutrition. Sasakawa Africa Association Newsletter 18, 4-5. 